\title{
Exploring the Effects of E-Cigarettes using Drosophila Melanogaster
}

\author{
Aditi Dosi ${ }^{1}$ and Jennifer Lambert-Peloquin ${ }^{1 \#}$ \\ ${ }^{1}$ Shrewsbury High School, Shrewsbury, MA, USA \\ \#Advisor
}

$\underline{\text { ABSTRACT }}$

\begin{abstract}
Although the number of vaping-related deaths in the US is rising, the specific cause remains unidentified. Therefore, determining what long-term effects vegetable glycerin (VG) and propylene glycol (PG), the main non-nicotine components in e-cigarettes, may have is crucial. Discovering that these components are harmful when tested on fruit flies (Drosophila melanogaster), a model organism, may suggest similar effects in humans. In this study, the number of offspring, changes in behavior, and phenotypic mutations in fruit flies were observed for the parent, F1, and F2 generations after the parent generation was exposed to one of four treatments of aerosolized solution. These included a $50 \% \mathrm{PG} / 50 \% \mathrm{VG}$, a $30 \% \mathrm{PG} / 70 \% \mathrm{VG}$, a $70 \% \mathrm{PG} / 30 \% \mathrm{VG}$, or no solution (control) using a nebulizer for 18 seconds each day, for two days. It was found that each experimental group had fewer offspring than the control. A two-sample T-test $(\alpha=0.05)$ was used to find that the size of the flies in the F1 generation was statistically significantly smaller in $2 / 3$ of the experimental groups when compared to the control. Furthermore, it was observed using a two-proportion Z-test $(\alpha=0.05)$ that $2 / 3$ of experimental groups in the parent generation, and all F1 experimental groups were statistically significantly more likely to develop at least one phenotypic mutation than the control. Additionally, statistically significant changes were seen in activity patterns and reflex immediately after exposure. Overall, it is probable that exposure to aerosolized VG and PG is a major problem.
\end{abstract}

\section{Introduction}

As of October 8, 2019, twenty-six vaping-related deaths have been confirmed, but the specific cause continues to remain unidentified ("Outbreak of Lung Injury Associated with E-cigarette Use or Vaping" 2019). Previously thought to just be a less harmful alternative for cigarette users, e-cigarettes have opened up a gateway to a rising number of teens using these harmful products (Mason, 2015).

E-cigarettes are battery-operated devices used to inhale an aerosol that often consists of propylene glycol, vegetable glycerin, flavorings, and nicotine ("What Do We Know About E-cigarettes?" 2019). These devices contain a cartridge that holds the e-liquid, an atomizer that heats up the liquid, a power source, and a mouthpiece ("Electronic Cigarettes (E-cigarettes)," 2019). These liquid sub-micron droplets can have harmful effects when inhaled by an individual, including cancer, respiratory illnesses, and heart disease ("Electronic Smoking Devices and Secondhand Aerosol," 2019).

Two of the main non-nicotine ingredients in the aerosol are humectants propylene glycol and vegetable glycerin. Although these ingredients are FDA-approved as liquids, when vegetable glycerol is heated, it has been shown that a variety of carbonyl compounds are produced, including formaldehyde, acrolein, and acetaldehyde. The heating of propylene glycol often results in the formation of formaldehyde and acetaldehyde ("Safety Data on Heated Vegetable Glycerin Vapor," 2019). These compounds can lead to irritation of the skin, eyes, and throat. High levels of exposure to formaldehyde, and acetaldehyde give the user risk for certain types of cancer. ("Safety Data on Heated Vegetable Glycerin Vapor," 2019). Overall, the specific long-term effects of the aerosolized ingredients propylene 
glycol and vegetable glycerin have scarcely been studied (Glantz, 2019). More extensive knowledge surrounding the long-term effects of these ingredients in their aerosol form is imperative.

While e-cigarettes are still relatively new devices, there has been research done to understand their effects. In one study, the effects of nebulized propylene glycol and vegetable glycerin were tested in mice to see what level of toxicity it had on mice over the course of about 3 months (Phillips et al., 2019). The study tested the effects of various concentrations of propylene glycol and vegetable glycerin with and without nicotine (Phillips et al., 2019). When exposed to the aerosolized, non-nicotine ingredients for 13 weeks 5 days each week, for 6 hours per day, the rats had slight changes in their breathing patterns (Phillips et al., 2019). All of the test subjects showed an increase in body weight over the course of the ninety-day exposure period (Phillips et al., 2019). The male mice had a slightly lower weight in groups that had vegetable glycerin, propylene glycol, and nicotine, while females had higher body weight than the rats that were not exposed to nicotine (Phillips et al., 2019). The study mainly focused on the toxic effects of the aerosol on the liver, respiratory system, and blood chemistry of the mice in a single generation (Phillips et al., 2019). Additionally, changes due to stress in behavior and weight were also observed in the rats, specifically in the females (Phillips et al., 2019).

Scientists have also been using fruit flies to test the effects of e-cigarettes since they are easy to work with and $60 \%$ of their genome corresponds to that of humans (Allocca et al., 2019). They have been able to discover that e-cigarette aerosol can lead to mutations in fruit flies. For instance, in one study, fruit flies were sorted into containers, containing ten male and female flies (Poulos). A volumetric pipet and bulb were used to administer ten puffs of ecigarette vapor to the flies (Poulos). The experiment showed that about $93 \%$ of flies had at least one mutation, and the number of offspring decreased by about $80 \%$ (Poulos).

Furthermore, in a study that explored the effects of maternal e-nicotine on offspring of Drosophila Melanogaster, the fruit flies were exposed to five millimeters of nicotine vapor eight times, for ten seconds with an interval of one hour (Merhie, Wagner, \& Krauss-Etschmann, 2018). The size, width, and development time were observed in the larvae, pupae, and hatched flies. (Merhie et al., 2018). There were developmental delays between the larvae and pupal stage (Merhie et al., 2018). As a consequence, the size and weight of the larvae were lower than that of the control group (Merhie et al., 2018).

Overall, these experiments suggest that exposure to e-cigarette aerosol is dangerous. Additionally, their results suggest that a more concrete understanding surrounding both the long-term effects of e-cigarette aerosol and the effects of specific ingredients is crucial. Thus, determining the long-term effects of propylene glycol and vegetable glycerin will help pinpoint the effects of specific ingredients and what effects they may have in the long run, contributing to the scientific research being done to explore what is causing a rising number of vape-related illnesses and deaths in the United States. Provided this information, this experiment will focus on what long-term effects the two of the main components in e-cigarette aerosol, vegetable glycerin and propylene glycol, can have on parent, first (F1), and second generation (F2) of the model organism, Drosophila melanogaster. This experiment will explore whether the growth, reproduction rate, and mutations in phenotypic expressions and behavior of the fruit flies will change in response to being exposed to aerosolized vegetable glycerin and propylene glycol in various concentrations. If various solutions of aerosolized vegetable glycerin and propylene glycol are administered to Drosophila, then it is hypothesized that there will be mutations in the phenotypic expression of the organisms, less offspring, and changes in behavior.

\section{Methods}

\section{Nebulizer}

To administer the aerosol consisting of propylene glycol and vegetable glycerin into the closed containers holding the fruit flies, a nebulizer was used. 


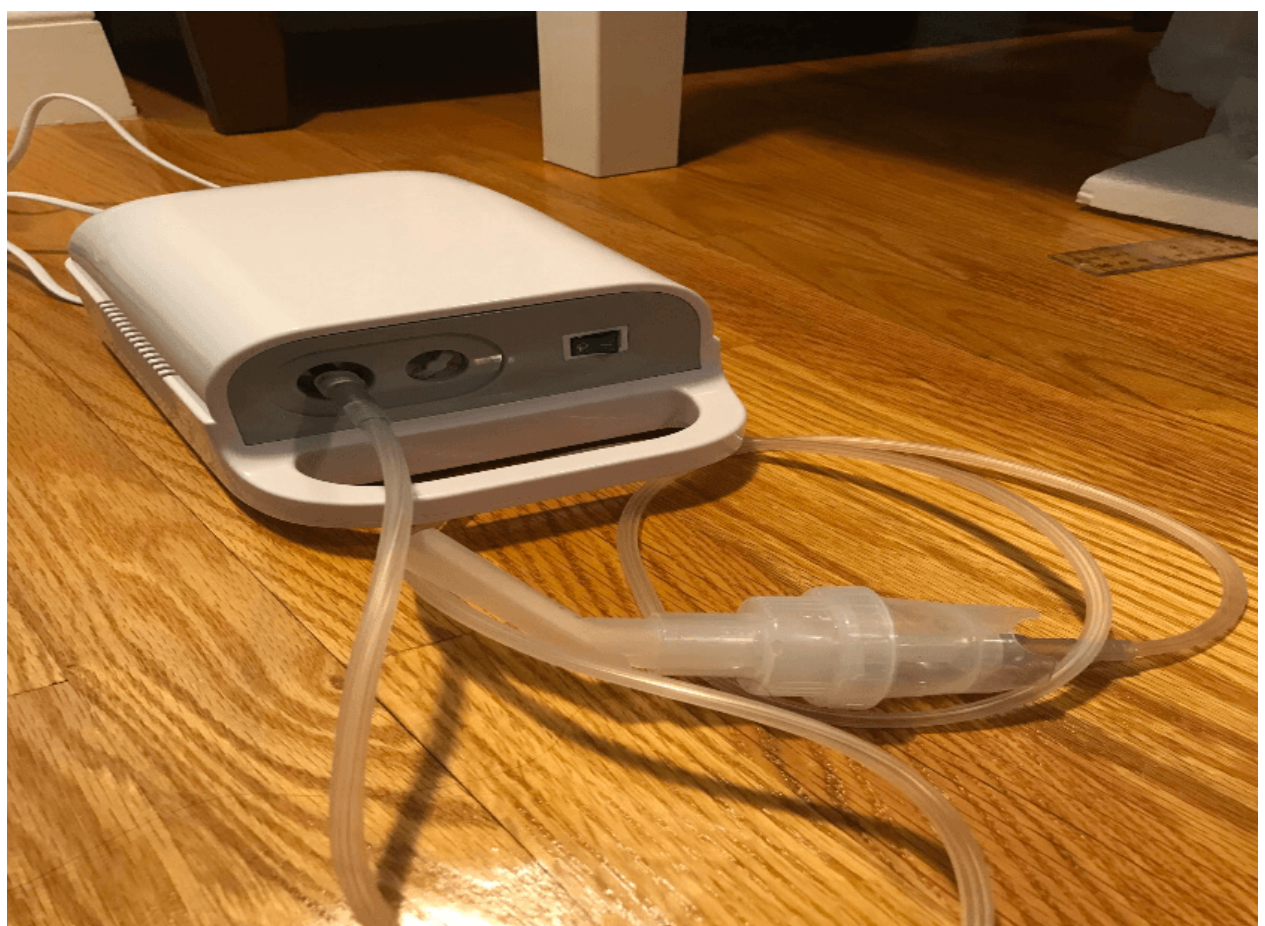

Figure 1. Image of the nebulizer used in this experiment. This is the nebulizer that was used to administer treatments of aerosol to the fruit flies on December 5th, 2019 and December 6th, 2019.

A nebulizer works by applying pressure to a liquid to produce a stream of small droplets of the liquid by forcing it through apertures (Miller 2015). The nebulizer was crucial to this experiment because it produced an aerosol through the process of pressurized air passing through its tubing. This aerosol was focused in a specific vial by placing the mouthpiece, the place where the aerosol exits, into the appropriate vial.

\section{Drosophila Melanogaster}

The fruit fly, Drosophila Melanogaster, was used in this experiment. This is because although simpler than mammals, the organism allows scientists to better understand human disease. The model organism is used widely throughout scientific research because its genome is sequenced, making it simple to manipulate and study specific genes (Allocca, Zola, \& Bellosta, 2019). Additionally, $75 \%$ of genes in humans that cause diseases are present in the fruit flies (Allocca et al., 2019). Furthermore, Drosophila are small organisms with a size of 2-3mm, they have a short generation time, they can easily be genetically modified, they are inexpensive, and they are easy to work with, making the organism crucial in education and research (Allocca et al., 2019). Throughout its average 10-day lifespan when raised at 25 degrees Celsius, a female fly can lay hundreds of eggs. (Allocca et al., 2019).

With Drosophila, it is easy to spot phenotypic mutations within generations. Common mutations include changes in their wing structure, body color, eye color, or formation of their head ("Mutant Fruit Flies"). 

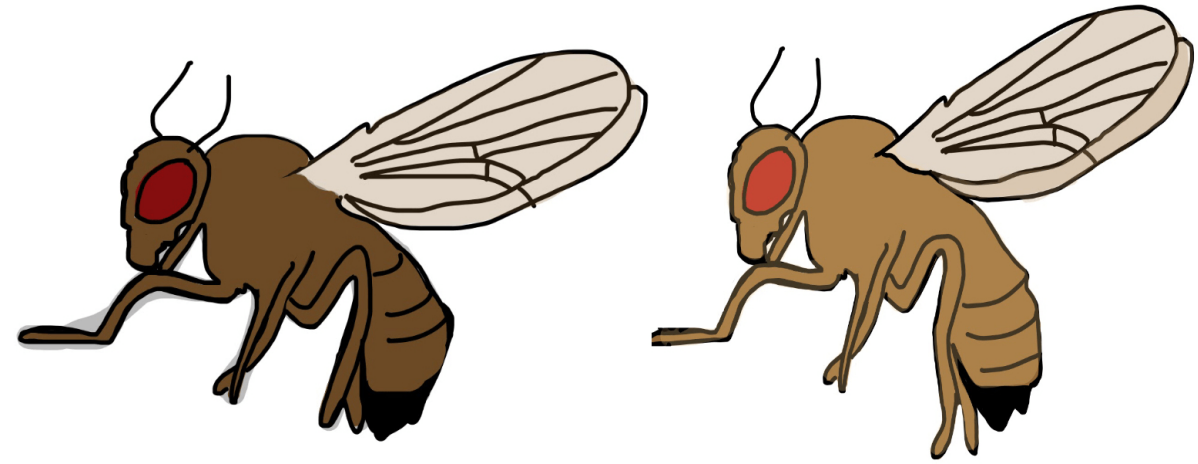

Figure 2. Illustration of a change in a fly's body color due to a mutation in its "ebony gene."

Changes in behavior may include changes in flight, sight, sensitivity, and circadian rhythms. Lastly, changes in reproduction rates and changes in growth are also commonly seen. These mutations and changes in behavior in fruit flies were observed in this experiment. Drosophila Melanogaster is a successful model organism and therefore, observations in changes in phenotype can be traced to genes that were altered, and in many cases, they can be traced back to humans (Allocca et al., 2019).

\section{Procedure}

This experiment was conducted by first sorting the fruit flies, with no visible mutations, into eight containers, and observing their behavior and phenotype. Observations that were made in regards to the behavior of the fruit flies involved observing their sensitivity to the smell of ripened food and sugary drinks, their sensitivity to light, and their rest and activity patterns. These observations were only made in the parent generation. Additionally, phenotypic mutations that were observed included observing changes in size, development, body shape, wing structure, legs, width, and the color of their bodies and eyes. These observations were made in each generation.

Prior to exposure, there were four vials containing females and four containing males. The vials were numbered 1-8. Each of the vials containing virgin females had 8 fruit flies, and the vials containing males had 16 flies in each of them.

\section{PRIOR TO CROSSING}
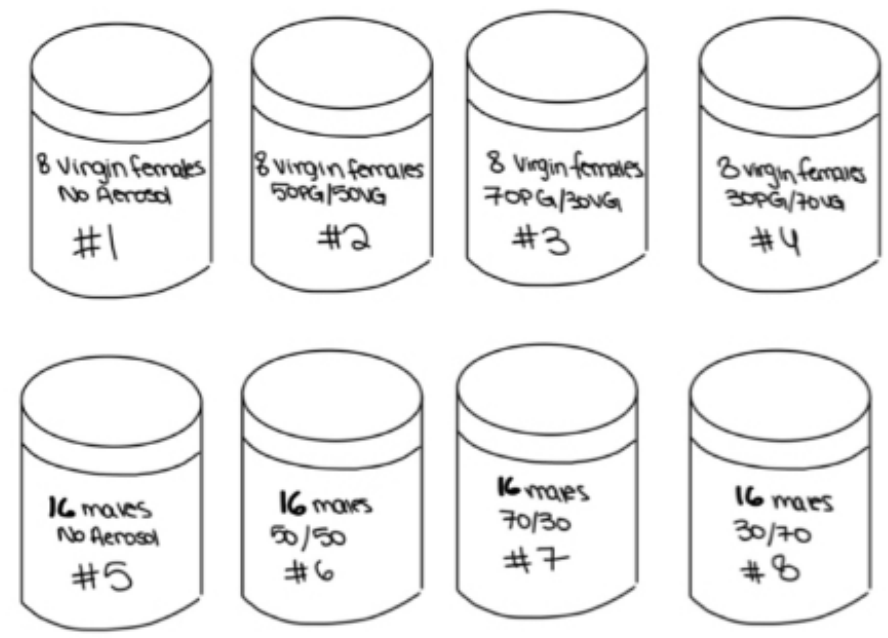
Figure 3. Illustration of the setup of vials prior to the fruit flies' exposure to a treatment of aerosol.

The flies were then exposed to either no aerosol (control), a 50\% propylene glycol to $50 \%$ vegetable glycerin solution (50/50), a 70\% propylene glycol to $30 \%$ vegetable glycerin solution $(70 / 30)$, or a $30 \%$ propylene glycol to $70 \%$ vegetable glycerin solution (30/70) for 18 seconds each day, for two days. Immediately after the flies were exposed to aerosol for the second, and last time, the behavior of the fruit flies was recorded. Following this, the flies were sorted into 16 vials, now with both males and virgin females in the same vials, and observations were recorded for about the next week. The vials were numbered 1-16. There were 2 females and 4 males in each vial. After this time period, the parent generation was euthanized and data regarding phenotype was recorded.

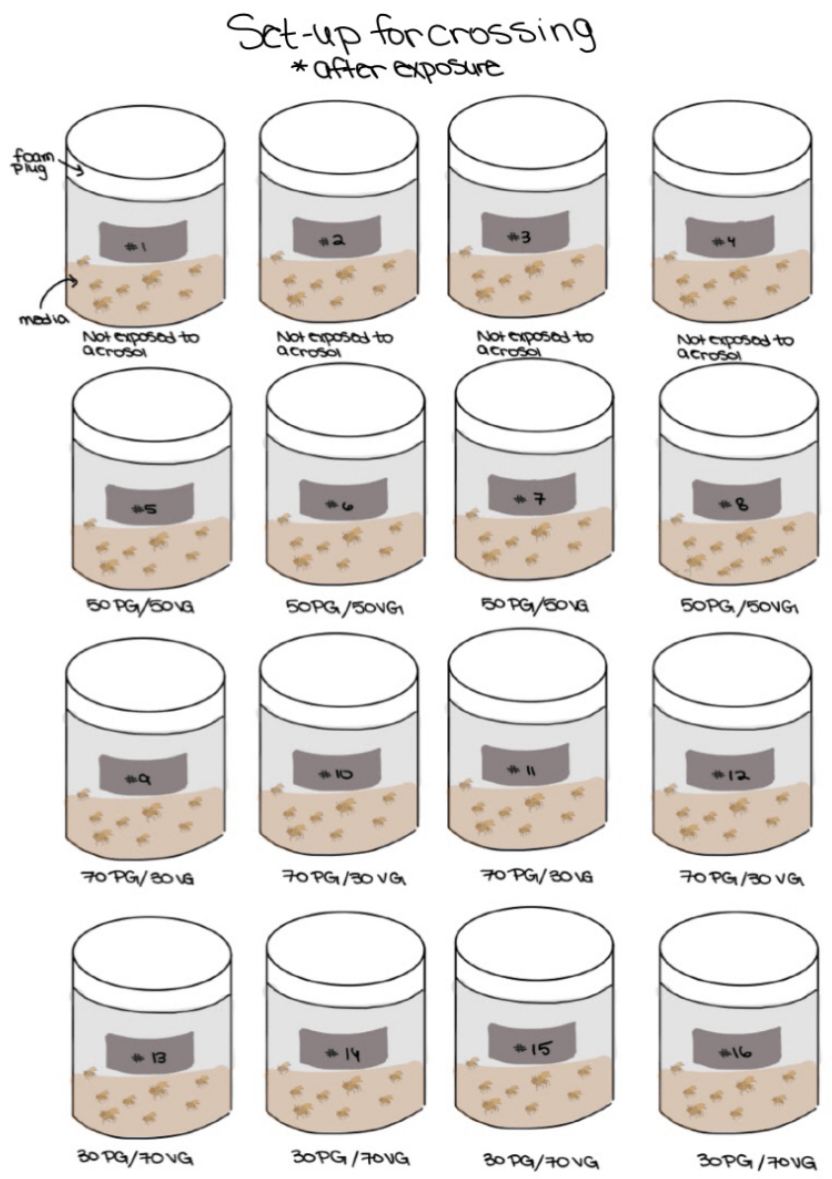

Figure 4. Illustration of the setup of vials after the fruit flies' exposure to a treatment of aerosol.

Once the F1 generation was born, data regarding behavior was recorded for about one week. This generation had an abundant number of flies and therefore, it had many trials, as each vial had upwards of 100 flies and each fly counted as 1 trial. This generation was also eventually euthanized about a week later, and data regarding phenotype and the number of flies was recorded. Lastly, once the F2 generation was born, the flies were euthanized and phenotypic observations were made. The number of flies in this generation was also recorded. This experiment took place at home in a room temperature environment, as well as at school where the aerosol was administered under a hood, so that any aerosol that was potentially released was sucked up. Data was recorded in tables separated by category and generation throughout the experimentation period (December 4th, 2019 - January 3rd, 2020). 


\section{Results}

\section{Phenotypic Mutations}

The length of the flies in the parent, F1, and F2 generations was used to determine whether there was statistical significance (SS) in the change in the size of the flies in each generation. In the parent generation (PG), the t-value, and p-value, and whether there was statistical significance was recorded by comparing the length of the flies exposed to each treatment of aerosol before and after their exposure to a treatment of aerosol or no aerosol (NA). The data recorded for the F1 and F2 generation was recorded by comparing the length of the flies exposed to the 50/50, 70/30, and $30 / 70$ solutions to the control group.

Table 1. Analysis regarding changes and mutations in length for the parent generation, the F1 generation, and F2 generation (2 sample T-test). Null hypothesis $\left(\mathrm{H}^{\circ}\right): \mu 1=\mu 2$. Alternative hypothesis $\left(\mathrm{H}^{\mathrm{a}}\right): \mu 1 \neq \mu 2$. Alfa value: 0.05 .

\begin{tabular}{|c|c|c|c|c|c|c|c|c|c|c|}
\hline & $\begin{array}{l}\text { Length } \\
\text { of flies } \\
\text { exposed } \\
\text { to NA } \\
\text { before } \\
\text { vs. after } \\
\text { (PG) }\end{array}$ & $\begin{array}{l}\text { Length of } \\
\text { flies ex- } \\
\text { posed to } \\
50 / 50 \text { be- } \\
\text { fore vs. } \\
\text { after ex- } \\
\text { posure } \\
\text { (PG) }\end{array}$ & $\begin{array}{l}\text { Length of } \\
\text { flies ex- } \\
\text { posed to } \\
70 / 30 \text { be- } \\
\text { fore vs. } \\
\text { after ex- } \\
\text { posure } \\
\text { (PG) }\end{array}$ & $\begin{array}{l}\text { Length of } \\
\text { flies ex- } \\
\text { posed to } \\
30 / 70 \text { vs. } \\
\text { after ex- } \\
\text { posure } \\
\text { (PG) }\end{array}$ & $\begin{array}{l}\text { Length } \\
\text { of flies } \\
\text { expose- } \\
\text { d to NA } \\
\text { vs. } \\
50 / 50 \\
(\mathrm{~F} 1)\end{array}$ & $\begin{array}{l}\text { Length } \\
\text { of flies } \\
\text { expos- } \\
\text { ed to } \\
\text { NA vs. } \\
70 / 30 \\
(\mathrm{~F} 1)\end{array}$ & $\begin{array}{l}\text { Length } \\
\text { of flies } \\
\text { expos- } \\
\text { ed to } \\
\text { NA vs. } \\
30 / 70 \\
(\mathrm{~F} 1)\end{array}$ & $\begin{array}{l}\text { Len- } \\
\text { gth of } \\
\text { flies } \\
\text { exp- } \\
\text { osed } \\
\text { to } \\
\text { NA } \\
\text { vs. } \\
50 / 50 \\
\text { (F2) }\end{array}$ & $\begin{array}{l}\text { Len- } \\
\text { gth of } \\
\text { flies } \\
\text { exp- } \\
\text { osed } \\
\text { to NA } \\
\text { vs. } \\
70 / 30 \\
(F 2)\end{array}$ & $\begin{array}{l}\text { Len- } \\
\text { gth of } \\
\text { flies } \\
\text { exp- } \\
\text { osed } \\
\text { to } \\
\text { NA } \\
\text { vs. } \\
30 / 70 \\
\text { (F2) }\end{array}$ \\
\hline $\begin{array}{l}\mathrm{t} \\
\text { value }\end{array}$ & 0.72 & 1.02 & 1.88 & 0.57 & 2.10 & 3.29 & 1.04 & 1.28 & -0.33 & -0.33 \\
\hline $\begin{array}{l}\mathrm{p} \\
\text { value }\end{array}$ & 0.48 & 0.31 & 0.85 & 0.57 & 0.04 & 0.00 & 0.30 & 0.23 & 0.75 & 0.75 \\
\hline SS? & No & No & No & No & Yes & Yes & No & No & No & No \\
\hline
\end{tabular}

The mean (M) and standard deviation (SD) of the size of all the flies exposed to no aerosol before the date of exposure in the parent generation, all the flies exposed to no aerosol after the date of exposure in the parent generation, all the flies exposed to the 50/50 solution before exposure in the parent generation, all the flies exposed to the 50/50 solution after exposure in the parent generation, all the flies exposed to the 70/30 solution before exposure in the parent generation, all the flies exposed to the 70/30 solution after exposure in the parent generation, all the flies exposed to the 30/70 solution before exposure in the parent generation, all the flies exposed to the 30/70 solution after exposure in the parent generation, and the all flies exposed to no aerosol, all the flies exposed to the 50/50 solution, all the flies exposed to the 70/30 solution, and all the flies exposed to the 30/70 solution in the F1 generation and F2 generations were determined using the lengths of flies in the parent, F1, and F2 generations.

Table 2. Mean and standard deviation regarding changes in length for the parent generation, F1 generation, and F2 generation. In the parent generation, data is recorded regarding the flies' lengths before (b4) and after (AF) exposure to a treatment of aerosol or no aerosol. Additionally, "SA" is the acronym used to represent "sample size" in the table. "Len" is the acronym used to represent the word "length." 


\begin{tabular}{|c|c|c|c|c|c|c|c|c|c|c|c|c|c|c|c|c|}
\hline & $\begin{array}{l}\text { NA } \\
\text { len } \\
\text { b4 } \\
\text { in } \\
\text { the } \\
\text { PG }\end{array}$ & $\begin{array}{l}\text { NA } \\
\text { len } \\
\mathrm{AF} \\
\text { in } \\
\text { the } \\
\mathrm{PG}\end{array}$ & $\begin{array}{l}50 / \\
50 \\
\text { len } \\
\text { b4 } \\
\text { in } \\
\text { the } \\
\text { PG }\end{array}$ & $\begin{array}{l}50 / \\
50 \\
\text { len } \\
\mathrm{AF} \\
\text { in } \\
\text { the } \\
\mathrm{PG}\end{array}$ & $\begin{array}{l}70 / \\
30 \\
\text { len } \\
\text { b4 } \\
\text { in } \\
\text { the } \\
\text { PG }\end{array}$ & $\begin{array}{l}70 / \\
30 \\
\text { len } \\
\mathrm{AF} \\
\text { in } \\
\text { the } \\
\mathrm{PG}\end{array}$ & $\begin{array}{l}30 / \\
70 \\
\text { len } \\
\text { b4 } \\
\text { in } \\
\text { the } \\
\text { PG }\end{array}$ & $\begin{array}{l}30 / \\
70 \\
\text { len } \\
\mathrm{AF} \\
\text { in } \\
\text { the } \\
\mathrm{PG}\end{array}$ & $\begin{array}{l}\text { NA } \\
\text { len } \\
\text { in } \\
\text { F1 }\end{array}$ & $\begin{array}{l}50 / \\
50 \\
\text { len } \\
\text { in } \\
\mathrm{F} 1\end{array}$ & $\begin{array}{l}70 / \\
30 \\
\text { len } \\
\text { in } \\
\mathrm{F} 1\end{array}$ & $\begin{array}{l}30 / \\
70 \\
\text { len } \\
\text { in } \\
\mathrm{F} 1\end{array}$ & $\begin{array}{l}\text { NA } \\
\text { len } \\
\text { in } \\
\text { F2 }\end{array}$ & $\begin{array}{l}50 / \\
50 \\
\text { len } \\
\text { in } \\
\text { F2 }\end{array}$ & $\begin{array}{l}\text { 70/ } \\
30 \\
\text { len } \\
\text { in } \\
\text { F2 }\end{array}$ & $\begin{array}{l}30 / \\
70 \\
\text { len } \\
\text { in } \\
\text { F2 }\end{array}$ \\
\hline $\mathrm{M}$ & 2.58 & 2.5 & 2.67 & 2.54 & 2.63 & 2.65 & 2.6 & 2.67 & 2.52 & 2.45 & 2.46 & 2.5 & 2.49 & 2.36 & 2.52 & 2.52 \\
\hline $\begin{array}{l}S \\
D\end{array}$ & .38 & .42 & .38 & .46 & .4 & .34 & .39 & .38 & .22 & .31 & .21 & .27 & .34 & .24 & .35 & .38 \\
\hline $\begin{array}{l}\mathrm{S} \\
\mathrm{A}\end{array}$ & 24 & 24 & 24 & 24 & 24 & 24 & 24 & 24 & 437 & 119 & 313 & 403 & 45 & 7 & 32 & 27 \\
\hline
\end{tabular}

Observations regarding the number of flies that developed a mutation in wing structure in each generation was used to determine the z-value, p-value, and whether there was statistical significance in developing a change or mutation in wing structure by comparing the fraction of all the flies exposed to no aerosol that developed a mutation in wing structure to the fraction of all the flies exposed to the 50/50 solution, the 70/30 solution, and the 30/70 solution that developed a mutation in wing structure in each generation.

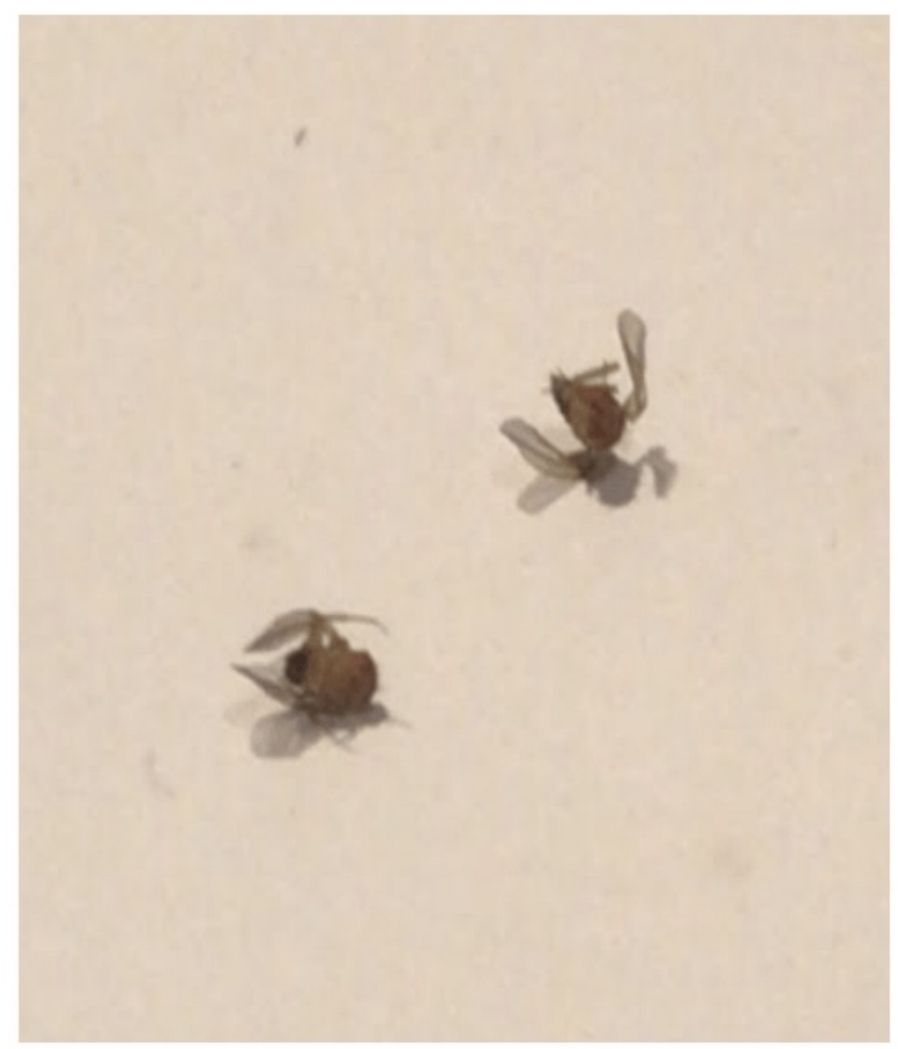

Figure 5. Image of a mutation in the "curly gene" of fruit flies. This image displays two of the many fruit flies that developed a mutation in their wing structure in which their wings became curly. These fruit flies were in the parent generation in vial \#8. They were exposed to the 50/50 treatment. 
In this experiment, mutations in the flies' "curly genes" in which their wings are curly rather than flat and mutation in their "vestigial genes" in which their wings are short were the changes in wing structure that were being observed.

Table 3. Analysis regarding the chance of developing at least one mutation in wing structure (WS) for the parent generation, F1 generation and F2 generation (2 Sample Z-test). Null hypothesis $\left(\mathrm{H}^{\mathrm{o}}\right): \mathrm{p} 1=\mathrm{p} 2$. Alternative hypothesis $\left(\mathrm{H}^{\mathrm{a}}\right): \mathrm{p} 1<\mathrm{p} 2$. Alfa value: 0.05 .

\begin{tabular}{|c|c|c|c|c|c|c|c|c|c|}
\hline & $\begin{array}{l}\text { WS of } \\
\text { NA vs. } \\
50 / 50 \\
\text { fruit } \\
\text { flies } \\
\text { (PG) }\end{array}$ & $\begin{array}{l}\text { WS of } \\
\text { NA vs. } \\
70 / 30 \\
\text { fruit } \\
\text { flies } \\
\text { (PG) }\end{array}$ & $\begin{array}{l}\text { WS of } \\
\text { NA vs. } \\
30 / 70 \\
\text { fruit } \\
\text { flies } \\
\text { (PG) }\end{array}$ & $\begin{array}{l}\text { WS of } \\
\text { NA vs. } \\
50 / 50 \\
\text { fruit flies } \\
\text { (F1) }\end{array}$ & $\begin{array}{l}\text { WS of } \\
\text { NA vs. } \\
70 / 30 \\
\text { fruit } \\
\text { flies } \\
\text { (F1) }\end{array}$ & $\begin{array}{l}\text { WS of NA } \\
\text { vs. } 30 / 70 \\
\text { fruit flies } \\
\text { (F1) }\end{array}$ & $\begin{array}{l}\text { WS of } \\
\text { NA vs. } \\
50 / 50 \\
\text { fruit } \\
\text { flies } \\
\text { (F2) }\end{array}$ & $\begin{array}{l}\text { WS of } \\
\text { NA vs. } \\
70 / 30 \\
\text { fruit } \\
\text { flies } \\
\text { (F2) }\end{array}$ & $\begin{array}{l}\text { WS of } \\
\text { NA vs. } \\
30 / 70 \\
\text { fruit } \\
\text { flies } \\
(\mathrm{F} 2)\end{array}$ \\
\hline z value & -1.04 & -3.57 & -2.32 & -6.54 & -7.55 & -6.38 & -1.54 & -0.9 & -0.37 \\
\hline $\mathrm{p}$ value & 0.15 & $1.77 \mathrm{E}-4$ & 0.01 & $3.07 \mathrm{E}-11$ & 0 & $8.69 \mathrm{E}-11$ & 0.61 & 0.18 & 0.36 \\
\hline SS? & No & Yes & Yes & Yes & Yes & Yes & No & No & No \\
\hline
\end{tabular}

Observations regarding the number of flies that developed a mutation in body color in the parent generation was used to determine the z-value, p-value, and whether there was statistical significance in developing a change or mutation in body color by comparing the fraction of all the flies exposed to no aerosol that developed a mutation in body color to the fraction of all the flies exposed to the 50/50 solution, the 70/30 solution, and the 30/70 solution that developed a mutation in body color in the parent generation (the only generation that flies had a change in body color in).

Table 4. Analysis regarding the chance of developing a mutation in body color for the parent generation ( 2 sample Ztest). Null hypothesis $\left(\mathrm{H}^{\mathrm{o}}\right): \mathrm{p} 1=\mathrm{p} 2$. Alternative hypothesis $\left(\mathrm{H}^{\mathrm{a}}\right): \mathrm{p} 1<\mathrm{p} 2$. Alfa value: 0.05 \begin{tabular}{l|l|l|l} 
Body Color of NA vs. & Body Color of NA vs. & Body Color of NA vs. \\
$\begin{array}{lll}50 / 50 \text { fruit flies }(\mathrm{PG}) & 70 / 30 \text { fruit flies }(\mathrm{PG}) & 30 / 70 \text { fruit flies }(\mathrm{PG})\end{array}$
\end{tabular}

\begin{tabular}{|l|l|l|l|}
\hline $\mathrm{z}$ value & -1.01 & -1.01 & -1.01 \\
\hline $\mathrm{p}$ value & 0.16 & 0.16 & 0.16 \\
\hline $\begin{array}{l}\text { Was there statistical sig- } \\
\text { nificance? }\end{array}$ & No & No & No \\
\hline
\end{tabular}

Observations regarding the number of flies that developed a phenotypic mutation in each generation was used to determine the z-value, $\mathrm{p}$-value, and whether there was statistical significance in developing a phenotypic mutation by comparing the fraction of all the flies exposed to no aerosol that developed a phenotypic mutation to the fraction of all the flies exposed to the 50/50 solution, the 70/30 solution, and the 30/70 solution that developed a phenotypic mutation in each generation. 
Table 5. Analysis regarding the chance of developing a mutation in phenotype (MP) overall for the parent generation, F1 generation, and F2 generation (2 sample Z-test). Null hypothesis $\left(\mathrm{H}^{\circ}\right)$ : $\mathrm{p} 1=\mathrm{p} 2$. Alternative hypothesis $\left(\mathrm{H}^{\mathrm{a}}\right)$ : $\mathrm{p} 1<$ p2. Alfa value: 0.05 .

\begin{tabular}{|c|c|c|c|c|c|c|c|c|c|}
\hline & $\begin{array}{l}\text { MP in } \\
\text { NA vs. } \\
50 / 50 \\
\text { fruit } \\
\text { flies } \\
(P G)\end{array}$ & $\begin{array}{l}\text { MP in } \\
\text { NA vs. } \\
70 / 30 \\
\text { fruit } \\
\text { flies } \\
\text { (PG) }\end{array}$ & $\begin{array}{l}\text { MP in } \\
\text { NA vs. } \\
30 / 70 \\
\text { fruit } \\
\text { flies } \\
\text { (PG) }\end{array}$ & $\begin{array}{l}\text { MP in } \\
\text { NA vs. } \\
50 / 50 \\
\text { fruit flies } \\
\text { (F1) }\end{array}$ & $\begin{array}{l}\text { MP in } \\
\text { NA vs. } \\
70 / 30 \\
\text { fruit } \\
\text { flies } \\
\text { (F1) }\end{array}$ & $\begin{array}{l}\text { MP in NA } \\
\text { vs. } 30 / 70 \\
\text { fruit flies } \\
\text { (F1) }\end{array}$ & $\begin{array}{l}\text { MP in } \\
\text { NA vs. } \\
50 / 50 \\
\text { fruit } \\
\text { flies } \\
\text { (F2) }\end{array}$ & $\begin{array}{l}\text { MP in } \\
\text { NA Vs. } \\
70 / 30 \\
\text { fruit } \\
\text { flies } \\
(\text { F2) }\end{array}$ & $\begin{array}{l}\text { MP in } \\
\text { NA vs. } \\
30 / 70 \\
\text { fruit } \\
\text { flies } \\
\text { (F2) }\end{array}$ \\
\hline $\mathrm{z}$ value & -1.42 & -3.57 & -2.32 & -6.54 & -7.55 & -6.38 & -1.54 & -0.9 & -0.37 \\
\hline $\mathrm{p}$ value & 0.08 & $1.77 \mathrm{E}-4$ & 0.01 & 3.07E-11 & 0 & $8.69 \mathrm{E}-11$ & 0.61 & 0.18 & 0.36 \\
\hline SS? & No & Yes & Yes & Yes & Yes & Yes & No & No & No \\
\hline
\end{tabular}

\section{Mortality Rate}

Observations that were made about the number of flies alive each day were used to represent the mortality rate of the flies exposed to no aerosol, the 50/50 solution, the 70/30 solution, and the 30/70 solution in the parent generation from December 8th - December 16th (after exposure to one of three treatments of aerosol or no aerosol).

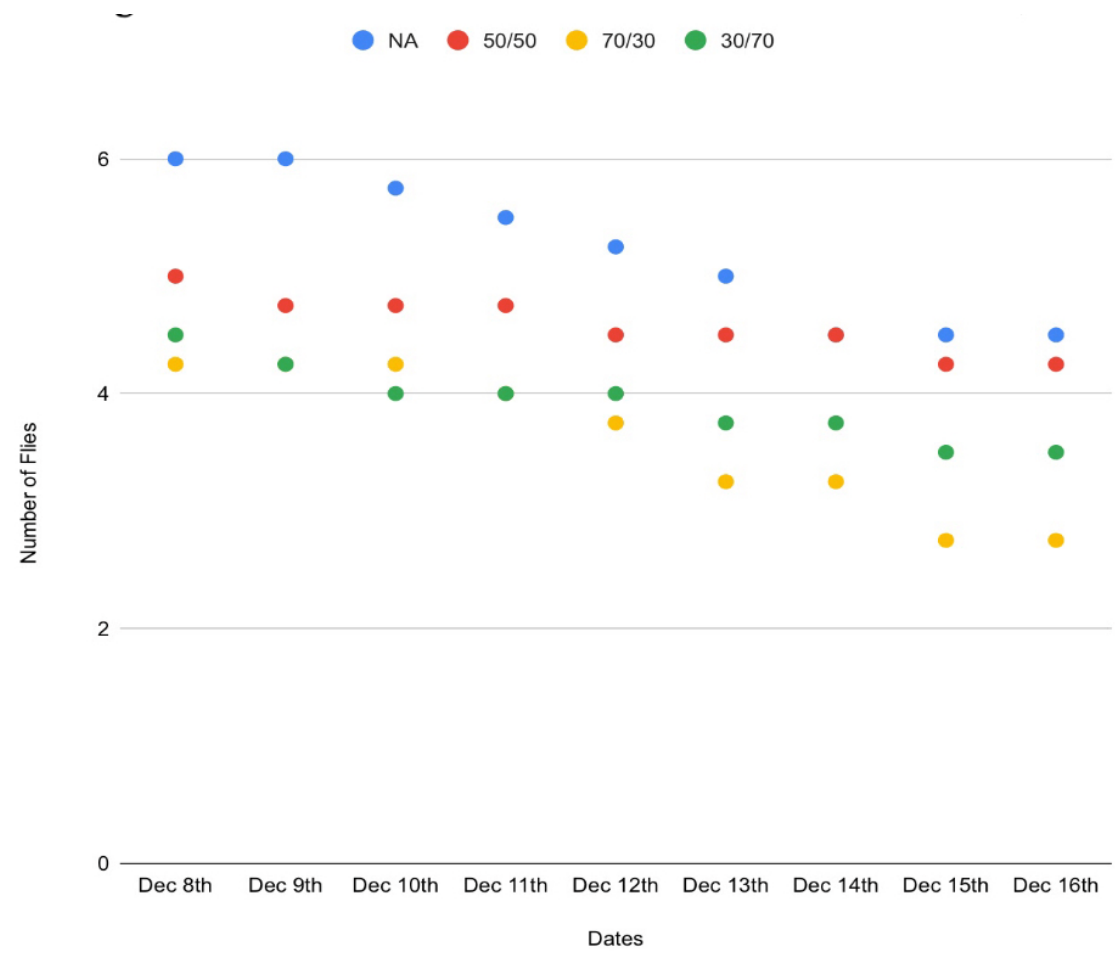

Figure 6. Analysis of mortality rate of the parent generation from December 8th - December 16th). 


\section{Behavior}

Observations involving the rest and activity patterns of flies in the parent generation were used to determine the $\mathrm{z}$ value, $\mathrm{p}$-value, and whether there was statistical significance in the number of flies that would moving/walking at 3:30 PM on December 6th (immediately after exposure) by comparing the fraction of flies that would be moving in the control group to the fraction that were moving in the 50/50, 70/30, and 30/70 groups in the parent generation. These calculations were also determined for the data recorded a week after exposure on December 13th at 6:35 PM. Observations were made immediately after exposure and a week later to get an idea of how aerosolized vegetable glycerin and propylene glycol can affect a person's behavior within a shorter period of time.

Table 6. Analysis regarding changes in rest and activity behavior in the parent generation (2 sample Z-test). Null hypothesis $\left(\mathrm{H}^{\mathrm{o}}\right): \mathrm{p} 1=\mathrm{p} 2$. Alternative hypothesis $\left(\mathrm{H}^{\mathrm{a}}\right)$ : $\mathrm{p} 1>\mathrm{p} 2$. Alfa value: 0.05

\begin{tabular}{|c|c|c|c|c|c|c|}
\hline & $\begin{array}{l}\text { Rest/Activity } \\
\text { of NA vs. } \\
50 / 50 \text { fruit } \\
\text { flies (PG) on } \\
\text { Dec 6th at 3:30 } \\
\text { PM }\end{array}$ & $\begin{array}{l}\text { Rest/Activity } \\
\text { of NA vs. } \\
70 / 30 \text { fruit } \\
\text { flies (PG) on } \\
\begin{array}{l}\text { Dec 6th at } \\
\text { 3:30 PM }\end{array}\end{array}$ & $\begin{array}{l}\text { Rest/Activity } \\
\text { of NA vs. } \\
30 / 70 \text { fruit } \\
\text { flies (PG) on } \\
\text { Dec 6th at 3:30 } \\
\text { PM) }\end{array}$ & $\begin{array}{l}\text { Rest/Activity } \\
\text { of NA vs. } \\
50 / 50 \text { fruit } \\
\text { flies (PG) on } \\
\text { Dec 13th at } \\
6: 35 \mathrm{PM}\end{array}$ & $\begin{array}{l}\text { Rest/Activity } \\
\text { of NA vs. } \\
70 / 30 \text { fruit } \\
\text { flies (PG) on } \\
\text { Dec 13th at } \\
6: 35 \text { PM) }\end{array}$ & $\begin{array}{l}\text { Rest/Activity of } \\
\text { NA vs. } 30 / 70 \\
\text { fruit flies (PG) } \\
\text { on Dec 13th at } \\
6: 35 \mathrm{PM})\end{array}$ \\
\hline $\mathrm{z}$ value & 4.29 & 3.92 & 3.25 & 4.29 & 3.92 & 3.25 \\
\hline $\mathrm{p}$ value & $9.08 \mathrm{E}-06$ & $4.37 \mathrm{E}-05$ & $5.84 \mathrm{E}-04$ & 9.08E-06 & $4.37 \mathrm{E}-05$ & $5.84 \mathrm{E}-04$ \\
\hline SS? & Yes & Yes & Yes & Yes & Yes & Yes \\
\hline
\end{tabular}

Observations surrounding the flies' movement in response to the vial being tapped was used to determine the z-value, p-value, and whether there was statistical significance in the number of flies that would immediately move/walk in response to tapping the vial once on 3:30 PM on December 6th (immediately after exposure) by comparing the fraction of flies that would be moving in the control group to the fraction that were moving in the 50/50, 70/30, and 30/70 groups in the parent generation. These calculations were also determined for the data recorded a week after exposure on December 13th at 6:35 PM.

Table 7. Analysis regarding changes in movement behavior in the parent generation ( 2 sample Z-test). Null hypothesis $\left(\mathrm{H}^{\mathrm{o}}\right): \mathrm{p} 1=\mathrm{p} 2$. Alternative hypothesis $\left(\mathrm{H}^{\mathrm{a}}\right)$ : $\mathrm{p} 1>\mathrm{p} 2$. Alfa value: 0.05.

\begin{tabular}{|c|c|c|c|c|c|c|}
\hline & $\begin{array}{l}\text { Movement of } \\
\text { NA vs. } 50 / 50 \\
\text { fruit flies } \\
\text { (PG) on Dec } \\
6 \text { th at } 3: 30 \\
\text { PM }\end{array}$ & $\begin{array}{l}\text { Movement of } \\
\text { NA vs. } 70 / 30 \\
\text { fruit flies } \\
\text { (PG) on Dec } \\
6 \text { th at } 3: 30 \\
\text { PM }\end{array}$ & $\begin{array}{l}\text { Movement of } \\
\text { NA vs. } 30 / 70 \\
\text { fruit flies } \\
\text { (PG) on Dec } \\
\text { 6th at } 3: 30 \\
\text { PM) }\end{array}$ & $\begin{array}{l}\text { Movement of } \\
\text { NA vs. } 50 / 50 \\
\text { fruit flies } \\
\text { (PG) on Dec } \\
\text { 13th at } 6: 35 \\
\text { PM }\end{array}$ & $\begin{array}{l}\text { Movement of } \\
\text { NA vs. } 70 / 30 \\
\text { fruit flies } \\
\text { (PG) on Dec } \\
\text { 13th at } 6: 35 \\
\text { PM) }\end{array}$ & $\begin{array}{l}\text { Movement of } \\
\text { NA vs. } 30 / 70 \\
\text { fruit flies } \\
\text { (PG) on Dec } \\
\text { 13th at } 6: 35 \\
\text { PM) }\end{array}$ \\
\hline z value & 3.84 & 3.58 & 3.84 & 0.64 & 1.51 & 0.93 \\
\hline $\mathrm{p}$ value & $6.23 \mathrm{E}-05$ & $1.73 \mathrm{E}-04$ & $6.23 \mathrm{E}-05$ & 0.26 & 0.07 & 0.175 \\
\hline
\end{tabular}




\begin{tabular}{|l|l|l|l|l|l|l|}
\hline $\begin{array}{l}\text { Was there sta- } \\
\text { tistical signif- } \\
\text { icance? }\end{array}$ & Yes & Yes & Yes & No & No & No \\
\hline
\end{tabular}

Observations about the number of flies that moved in response to a light in the parent generation was used to determine the z-value, p-value and whether there was statistical significance in the number of flies that would move/walk towards the light source on 3:30 PM on December 6th (immediately after exposure) by comparing the fraction of flies that would be moving in the control group to the fraction that were moving in the 50/50, 70/30, and 30/70 groups in the parent generation. These calculations were also determined for the data recorded a week after exposure on December 13th at 6:35 PM.

Table 8. Analysis regarding changes in light behavior in the parent generation (2 sample Z-test). Null hypothesis $\left(\mathrm{H}^{\mathrm{o}}\right)$ : $\mathrm{p} 1=\mathrm{p} 2$. Alternative hypothesis $\left(\mathrm{H}^{\mathrm{a}}\right)$ : $\mathrm{p} 1>\mathrm{p} 2$. Alfa value: 0.05 .

\begin{tabular}{|c|c|c|c|c|c|c|}
\hline & $\begin{array}{l}\text { Light behav- } \\
\text { ior of NA vs. } \\
50 / 50 \text { fruit } \\
\text { flies (PG) on } \\
\text { Dec 6th at } \\
\text { 3:30 PM }\end{array}$ & $\begin{array}{l}\text { Light behav- } \\
\text { ior of NA vs. } \\
70 / 30 \text { fruit } \\
\text { flies (PG) on } \\
\text { Dec 6th at } \\
\text { 3:30 PM }\end{array}$ & $\begin{array}{l}\text { Light behav- } \\
\text { ior of NA vs. } \\
\text { 30/70 fruit } \\
\text { flies (PG) on } \\
\text { Dec 6th at } \\
\text { 3:30 PM }\end{array}$ & $\begin{array}{l}\text { Light behav- } \\
\text { ior of NA vs. } \\
50 / 50 \text { fruit } \\
\text { flies (PG) on } \\
\text { Dec 13th at } \\
6: 35 \text { PM }\end{array}$ & $\begin{array}{l}\text { Light behav- } \\
\text { ior of NA vs. } \\
70 / 30 \text { fruit } \\
\text { flies (PG) on } \\
\text { Dec 13th at } \\
6: 35 \text { PM }\end{array}$ & $\begin{array}{l}\text { Light behav- } \\
\text { ior of NA vs. } \\
30 / 70 \text { fruit } \\
\text { flies (PG) on } \\
\text { Dec 13th at } \\
6: 35 \text { PM }\end{array}$ \\
\hline z value & -0.47 & -1.85 & -0.47 & 0.67 & 0.67 & 0.67 \\
\hline $\mathrm{p}$ value & 0.68 & 0.97 & 0.68 & 0.25 & 0.25 & 0.25 \\
\hline $\begin{array}{l}\text { Was there sta- } \\
\text { tistical signif- } \\
\text { icance? }\end{array}$ & No & No & No & No & No & No \\
\hline
\end{tabular}

\section{Discussion}

Using the analyzed data, it can be supported with $95 \%$ confidence that in the F1 generation, the flies that were the offspring of the flies in the parent generation that were exposed to the 50/50 or 70/30 solution were likely to develop a change in length (become smaller). Furthermore, the standard deviation for each of the tests was lower than 0.50 , meaning that the data was clustered around the mean and consistent. More specifically, the standard deviation of the lengths of the flies in the 50/50 solution group for the F1 generation was 0.31 , the mean was 2.45 and the sample size was 119. The standard deviation of the flies in the 70/30 solution group in the F1 generation was 0.21 , the mean was 2.46 and the sample size was 313. Overall, the low standard deviations show that the data was not widely spread out. Additionally, the fact that the means were lower than 2.52, the mean of the non-aerosol group in the F1 generation, shows that the flies were significantly smaller. But when comparing the length of the flies that were offspring of the flies exposed to no aerosol to the flies that were the offspring of the flies exposed to the 30/70 solution in the F1 generation, the p-value was 1.04 which is higher than the alpha value. Additionally, the p-values were higher than alpha values for each of the tests in the F2 generation meaning there was no statistical significance in the change in length for the F2 generation. For mutations in wing structure, flies in the parent generation that were exposed to the $70 / 30$ solution, the $30 / 70$ solution, as well as all flies in the experimental groups in the F1 generation were likely to develop at least one mutation in wing structure. This includes mutations in their "curly gene" and mutations in their "vestigial gene." Flies in the parent generation exposed to the 70/30 solution, the 30/70 solution, as well as all flies in 
the experimental groups in the F1 generation were also likely to develop at least one phenotypic mutation overall. For mortality rate, using averages it can be observed that the fruit flies exposed to any aerosol solution had a higher mortality rate.

Additionally, in terms of behavior, immediately after exposure, as well as a week after, there are significantly less flies moving in the vials exposed to aerosol than the ones that were not when they were observed, suggesting a change in rest and activity patterns. In terms of the number of flies that would move in response to tapping the vial, there were significantly less flies that were moving on December 6th at 3:30 PM, suggesting changes in their reflexes. Overall, changes and mutations were not seen in the body shape of each fly, the eye color of each fly, the number of legs each fly has, their behavior related to food, and their behavior related to light, as this data stayed relatively consistent between different generations, as well as between the control and experimental group.

\section{Conclusion}

To conclude, it is highly probable that vegetable glycerin and propylene glycol are dangerous in their aerosol state. Overall, parts of the hypothesis were supported while others were not. This is because there was a decrease in offspring produced in groups exposed to aerosol, there was a decrease in size for the 50/50 and 70/30 aerosol groups in the F1 generation, and there were some mutations in phenotype and behavior. Furthermore, the fact that there were changes and mutations in behavior and phenotype in the parent generation shows that this aerosol can not only have long term effects in future generations, but also within a single generation.

The information gathered will contribute to the scientific research being done to pinpoint what is causing a rising number of vape-related illnesses and deaths. Although the hypothesis cannot be proven, it can be supposed that vegetable glycerin and propylene glycol are not healthy in their aerosol form within a lifetime and in the long run. Therefore, consumption should be limited. Throughout the experiment, the understanding of the specific effects of these ingredients, the ability to work with fruit flies, the understanding of how to write a research paper, and the knowledge that it is not just the nicotine that has bad effects in e-cigarettes, but also the vegetable glycerin and propylene glycol were acquired.

There are many directions future researchers can go in to further their understanding surrounding the longterm effects of e-cigarettes. For instance, to expand on the results of this experiment the flies could be exposed to the aerosol for a longer period of time to better replicate how much aerosol a human may be exposed to. Additionally, a $100 \% \mathrm{VG}$ and a $100 \%$ PG solution can be used to determine the specific effect of each ingredient so that people can be more cautious of the amount of each ingredient in the aerosol they are vaping. In terms of testing the same question, this experiment could have been conducted using the zebrafish, a model organism that is also small in size, has a short life lifetime, and can easily mutate, making it helpful to observe disease. Moreover, the structures of their organs are similar to that of humans. Overall, in a world in which the number of vaping related deaths is rising, this knowledge will help researchers gain a better understanding of the aerosols making up these devices.

\section{Limitations}

It is also important to review the limitations of this project. One factor that may have affected the outcome of the experiment is that the flies were often being put in the freezer and being transferred from vial to vial using a brush. This may have killed some flies or affected their wing structure. Also, during the process of transferring flies, a small number of flies escaped. Additionally, some vials had slightly more food than others. Moreover, the nebulizer had a slight variation in the amount of aerosol it would release, so some vials may have gotten more aerosol than others. In terms of the ingredients being converted to an aerosol, the vegetable glycerin was much thicker than the propylene 
glycol, so slightly less aerosol was released by the nebulizer when the solution contained vegetable glycerin. Furthermore, there could be human error surrounding measurements and data recorded for all generations, especially for the F1 generation as most groups had more than 100 flies. Along these lines, the total number of flies in the F1 and F2 generation may be off. If flies were not seen and removed when they were supposed to be, they may have contributed to the total number of flies in the next generation. Some flies also got stuck in the food throughout the experiment, so it is quite probable that some of them were never seen at all. Lastly, near the end of the experiment, the F2 generation's food began to harden in some vials which may have contributed to the reduced chance of survival of the fruit flies in this generation.

\section{Acknowledgements}

I would like to thank Mrs. Peloquin for supporting me with my project and providing me with resources and a lab I could administer the aerosol. This project would not have been possible without her assistance.

\section{References}

About Electronic Cigarettes. (2019). Retrieved from http://www.casaa.org/electronic-cigarettes/

Allocca, M, Zola, S, \& Bellosta P. (2018, February). The Fruit Fly, Drosophila melanogaster: The Making of a Model (Part I). (2018, February). Trento, Italy: Intech

ECigStats. (2018). Retrieved from https://www.ecigstats.org/global-stats/

Electronic Cigarettes (E-cigarette). (2019, September). Retrieved from

https://www.drugabuse.gov/publications/drugfacts/electronic-cigarettes-e-cigarettes

Electronic Smoking Devices and Secondhand Aerosol. (2019). Retrieved from https://no-smoke.org/electronic-smoking-devices-secondhand-aerosol/

Glantz, S, A. (2019, September 7). PG/VG in ecigs tied to lung damage in well-done experiment. Retrieved from https://tobacco.ucsf.edu/pgvg-ecigs-tied-lung-damage-well-done-experiment

How to use a nebulizer.(2019,October2).Retrieved from https://medlineplus.gov/ency/patientinstructions/000006.htm

Mason, E. (2015, April 17). E-cigarette battle heats up. The Harvard Gazette. Retrieved from https://news.harvard.edu/gazette/

Merhie N, E, Wagner, C, \& Krauss-Etschmann S. (2018, February). Drosophila melanogaster as a model to study effects of maternal e-nicotine exposure on offspring. Retrieved from https://www.researchgate.net/profile/Natalia_El Merhie/publication/327841941 Drosophila melanogaster as a model to study effects of maternal e-nicotine exposure on offspring/links/5ba8d63a92851 ca9ed218689/Drosophila-melanogaster-as-a-model-to-study-effects-of-maternal-e-nicotine-exposure-on-offspring.pdf?origin=publication detail

Miller, C. (2014). Drosophila Melanogaster. Retrieved from https://animaldiversity.org/accounts/Drosophila_melanogaster/\#physical description 
Mutant Fruit Flies. Retrieved from https://annex.exploratorium.edu/exhibits/mutant flies/mutant flies.html

Nebulizer. (2019). Retrieved from https://www.sciencedirect.com/topics/pharmacology-toxicology-and-pharmaceutical-science/nebulizer

Outbreak of Lung Injury Associated with E-cigarette Use, or Vaping. (2019, October 11). Retrieved from https://www.cdc.gov/tobacco/basic_information/e-cigarettes/severe-lung-disease.html

Poulos, L. The Effects of E-Cigarette Vapor on Drosophila melanogaster. Retrieved from https://abstracts.societyforscience.org/Home/PrintPdf/10570

Richter, L. (2018, October). What is Vaping? Retrieved From https://www.centeronaddiction.org/e-cigarettes/recreational-vaping/what-vaping

Safety Data on Heated Vegetable Glycerin Vapor. (2019). Retrieved from https://monq.com/science/vegetable-glyc$\underline{\text { erin/ }}$

What Do We Know About E-cigarettes? (2019). Retrieved from https://www.cancer.org/cancer/cancer-causes/tobacco-and-cancer/e-cigarettes.html

What's in Your E-Cigarette? (2019). Retrieved from https://www.webmd.com/smoking-cessation/news/20150218/ecigarette-ingredients $\# 2$ 